\title{
A MORFOLOGIA DOS TECIDOS URBANOS DE INFLUÊNCIA INGLESA DA CIDADE DE NOVA LIMA
}

\author{
THE ENGLISH INFLUENCE ON THE TYPE MORPHOLOGICAL FABRICS OF \\ NOVA LIMA TOWN
}

\begin{abstract}
Staël de Alvarenga Pereira Costa
Arquiteta e urbanista (EAUFMG), master of Arts in Urban Design (Oxford Polytechnic), doutora em Arquitetura e Urbanismo, Estruturas Ambientais Urbanas (FAUUSP) e professora da Escola de Arquitetura/ UFMG - Departamento de Urbanismo.

e-mail: spcosta@arq.ufmg.br
\end{abstract}

\section{RESUMO}

Este trabalho apresenta resultados de uma pesquisa' desenvolvida em uma cidade remanescente do período colonial de Minas Gerais, Nova Lima.

Essa cidade apresenta, na forma urbana, um mosaico de experiências urbanas resultantes de políticas implementadas por companhias estrangeiras que aí se estaleceram após a extinção do ouro de aluvião. Quando o ouro de aluvião se esgota, o governo imperial brasileiro implementa políticas de atração do capital estrangeiro para a exploração subterrânea do ouro. Diversas companhias, inglesas principalmente, são atraídas a Minas Gerais para explorar ouro, ferro e diamantes no período de 1822 a 1889. Essas trazem tecnologia de ponta, trabalhadores qualificados e, para abrigá-los, foram postas em execução políticas habitacionais influenciadas pelos modelos de companhias industriais inglesas, do período vitoriano, que foram anexadas à antiga malha colonial das cidades mineiras.

Pode-se afirmar que esses modelos urbanísticos testados no interior do Brasil atuam como laboratórios de experiências urbanísticas as quais, posteriormente, dão origem às "cidades jardins".

Todos esses padrões estão presentes na estrutura urbana da cidade de Nova Lima e constituem tecidos urbanos diferenciados dos tradicionais, que se encontram em processo de transformação e adaptação.

Este trabalho mostra os diferentes tecidos urbanos daquela cidade, resultantes dessa política habitacional, e destaca sua importância como modelo de urbanização adotado em todas as cidades industriais implantadas posteriormente no estado de Minas Gerais.

Palavras-chave: Tecido urbano, companhias industriais vitorianas inglesas, Nova Lima, influência britânica.

\footnotetext{
ABSTRACT

This work presents study underdone in a colonial town settled in Minas Gerais state, Brazil. This town named Nova Lima presents in its urban form a mosaic of urban experiences resulted from several urban tendencies brought to it by foreign companies to exploit gold. When gold was rare on the ground floor the Imperial brazilian court put forward a policy to bring foreign companies to exploit gold underneath earth.

Several companies arrived in Minas Gerais to exploit gold, iron and diamonds from 1822 to 1889, mainly english. They brought technology, skilled workers and in order to settle them those companies implemented all facilities such as typical english victorian industrial towns, added to the former colonial core of that town. It can be said that those companies tested victorian principles in hinterland Brazil in the XIX Century and it can be also said that they acted as laboratories for urban theories that were further developed and known as garden cities.

All these models can be found in Nova Lima town and they form different from the traditional urban fabric and they are also experimenting change and transformations.
} 
This paper presents the different typo morphological patterns of this town to discuss its role as urban model that was followed by the industrial cities that were implemented in the Minas Gerais state after that.

Key words: Urban fabric, english model company towns, Nova Lima, and british influence.

\section{1 - A ESTRUTURA DA PAISAGEM URBANA DE NOVA LIMA EM 2005}

A cidade de Nova Lima é estruturada por vias de acesso que se conectam ao núcleo histórico, o centro principal de serviços e do comércio. $\bigcirc$ núcleo central se consolidou ao longo de um eixo de penetração que condicionava a ocupação urbana, na época colonial.

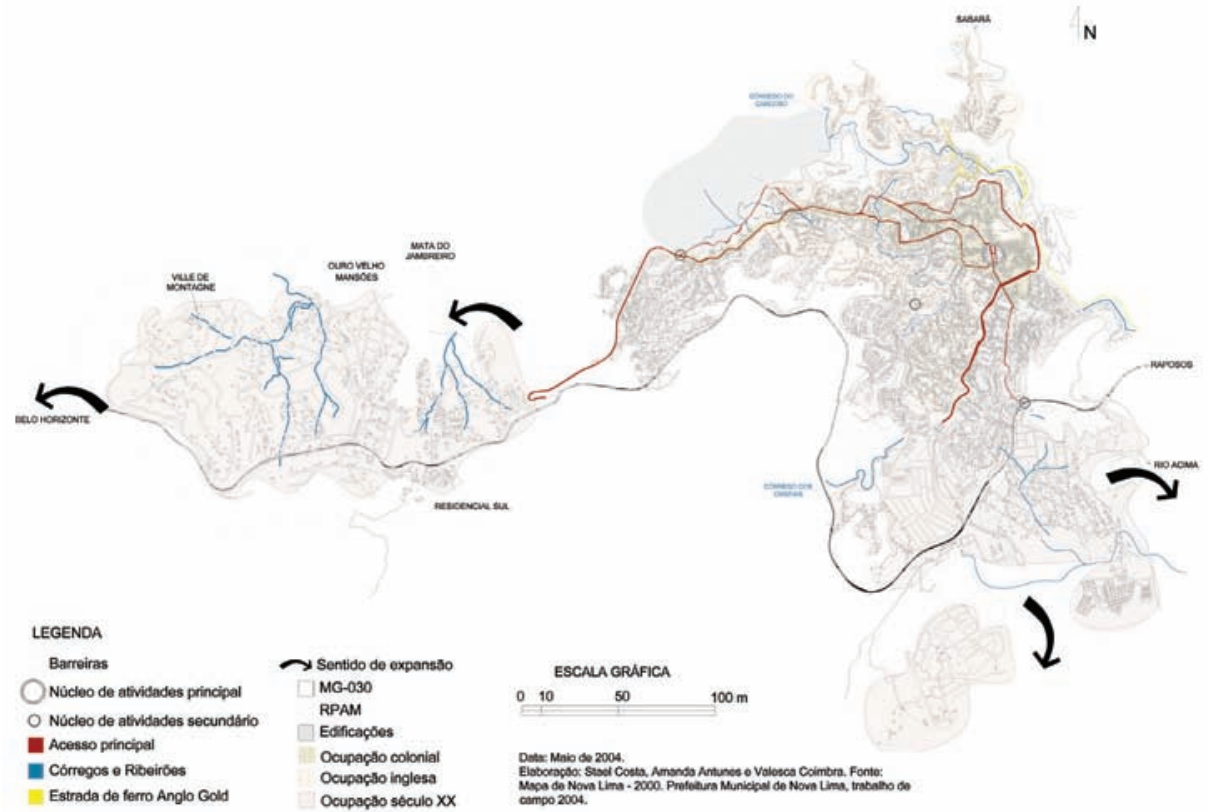

Figura 1: Mapa de estrutura urbana de Nova Lima

Créditos: Stael Costa, Amanda Antunes e Valesca Coimbra

Fonte: Mapa de Nova Lima, 2000. Prefeitura Municipal de Nova Lima, trabalho de campo, 2004

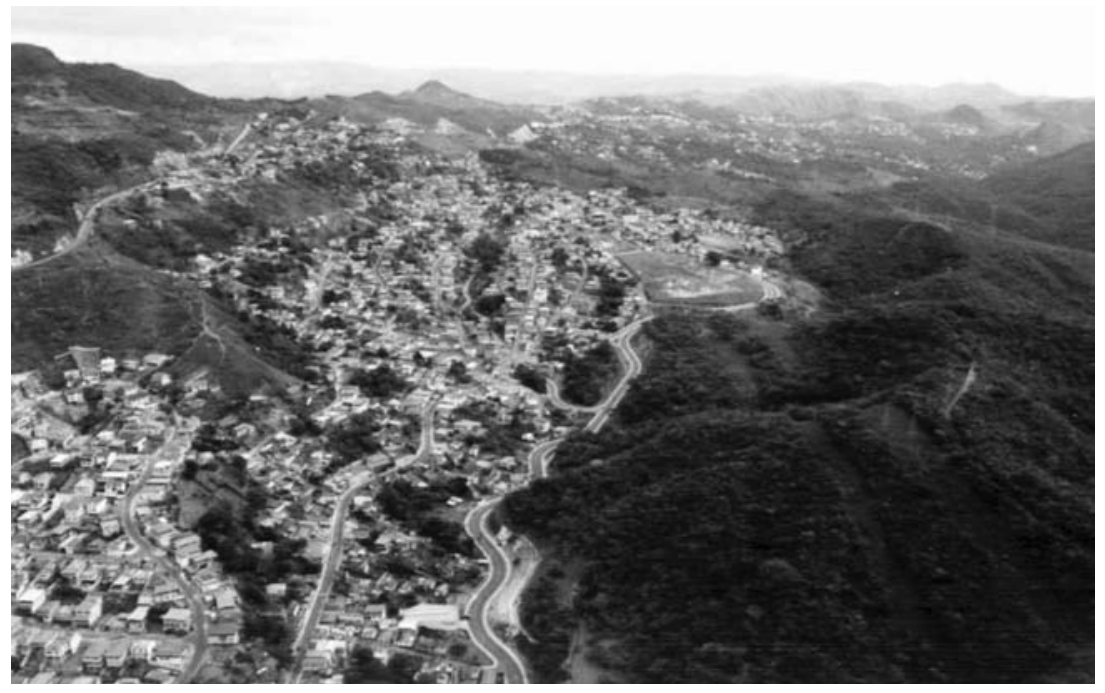

Figura 2:

A estrutura urbana de Nova Lima em 2001

Crédito: Foto de

Silvio Macedo 
Esse núcleo é contornado ao norte, noroeste e ao sul pela urbanização implantada pela Companhia Saint John Del Rey no século XIX e destaca-se pelo traçado orgânico e baixa densidade populacional. Por outro lado, a parte sudoeste e a parte leste da cidade resultam da expansão do antigo eixo colonial e assentam-se em áreas de alta declividade, constituindo-se de tecidos habitacionais densos de periferia pobre, típicos produtos da urbanização do século XX.

\section{2 - OS CONDICIONANTES DA FORMA URBANA DE NOVA LIMA}

A forma urbana de Nova Lima é estruturada por dois córregos, o dos Cristais e o Cardoso, limitados por vales encaixados e encostas íngremes. O córrego dos Cristais, o principal, secionou a forma urbana durante séculos e esta se desenvolveu, a princípio, nas direções norte e oeste, no vale estreito delimitado por duas bacias hidrográficas.

O relevo e a estrutura fundiária direcionam a forma urbana que se implanta no vale situado entre os terrenos da mina de Morro Velho e o córrego dos Cristais. As novas ocupações seguem essas direções e consolidam a forma da cidade como típica de vales encaixados e de alta declividade, nos quais as ligações viárias se interconectam a um eixo principal a induzir o aparecimento de novas áreas que seguem o mesmo modelo.

A sede do município contém dez tipos de tecidos urbanos, identificados por números de 1 a 10, a refletirem a ação dos diversos agentes econômicos que deixaram sua marca em sua forma urbana. Esta é condicionada pela forte característica do relevo, o que proporciona ao pedestre pequenos vislumbres de partes dessa paisagem urbana.

Dentre os dez tecidos urbanos identificados na forma urbana dessa cidade, alguns se destacam, seja pelo traçado orgânico ou em malha ortogonal, seja pelos tipos residenciais e não-residenciais. Todos possuem, porém, uma determinada tipicidade que permite sua caracterização como tecidos urbanos resultantes das normas urbanísticas inspiradas nos mo-

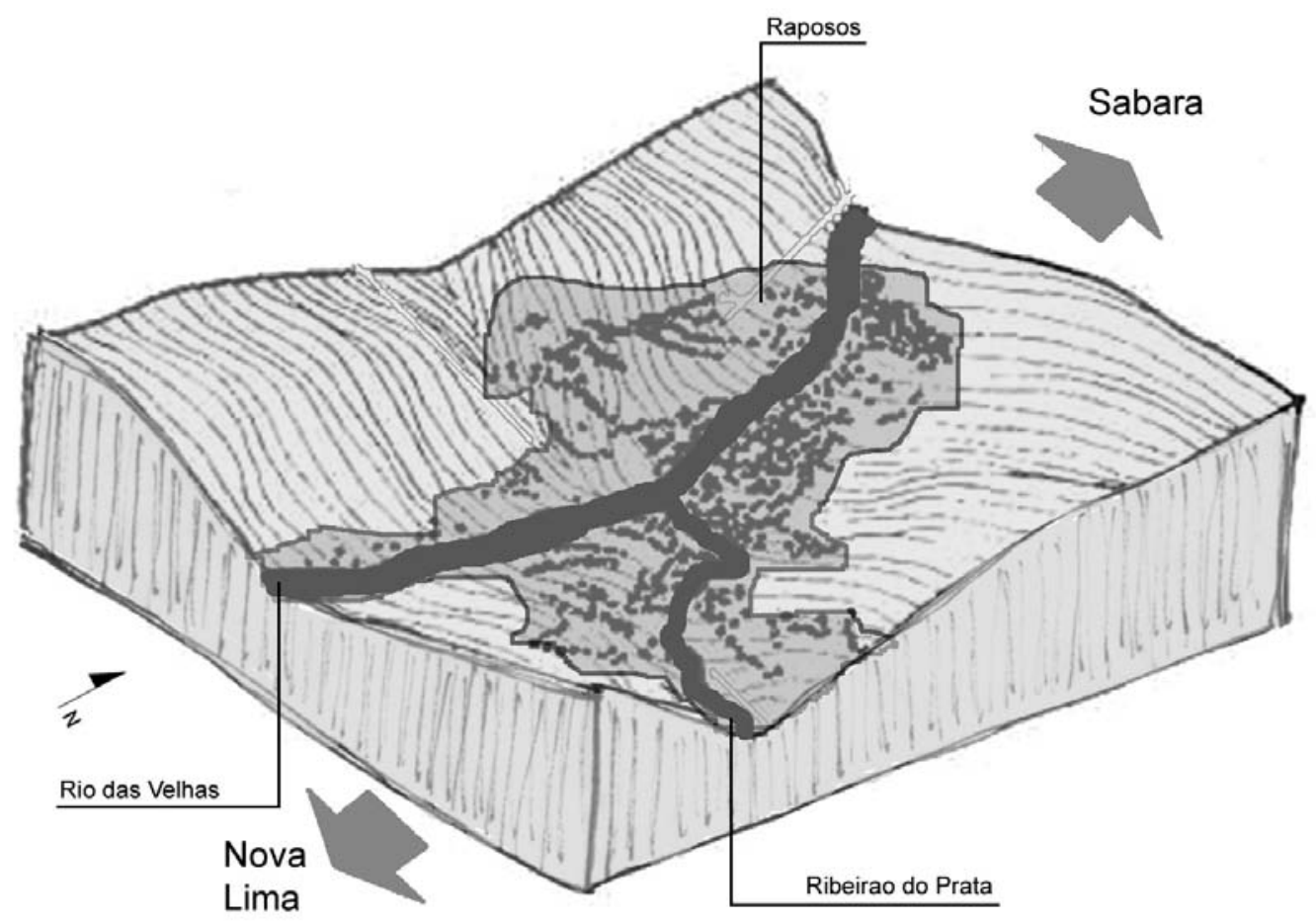

Figura 3: Croqui tridimensional ilustrativo da importância do relevo na conformação da forma urbana Crédito: Desenho de Flávia Amorim, 2002 


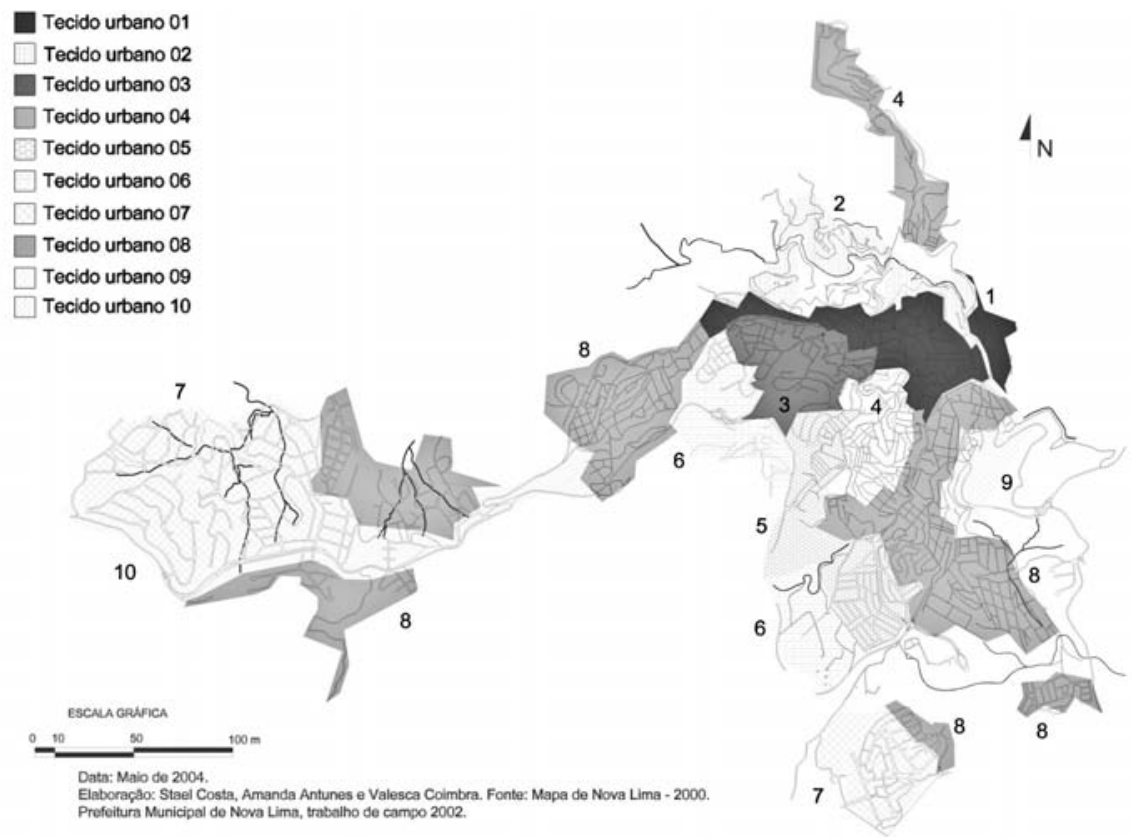

Figura 4: Mapa dos tecidos urbanos de Nova Lima

Créditos: Stael Costa, Amanda Antunes e Valesca Coimbra

Fonte: Mapa de Nova Lima, 2000. Prefeitura Municipal de Nova Lima, trabalho de campo, 2002

delos urbanísticos das companhias inglesas de influência vitoriana. Esses tecidos foram sendo implantados a partir de 1843 e constituem parte importante no estudo das formas urbanas dessa cidade, como se observa a seguir.

\section{3 - PROCEDIMENTOS METODOLÓGICOS}

Para se identificar as formas construídas de acordo com a normas de uma "model company towns", foi necessário adotar determinadas premissas para condução da investigação e posterior análise. Adotou-se a premissa da paisagem vista como sistema ${ }^{2}$ porque esta reflete não só uma relação de parte com o todo (a cidade com a região), mas, principalmente, a relação do suporte com a cobertura.

A segunda premissa é a que considera a paisagem como produto ${ }^{3}$ e, neste caso, tomase como produto as formas as quais refletem a ação da sociedade, como se observa em Magnolit:

\footnotetext{
"Paisagem é o suporte físico no qual se estrutura a sociedade cuja morfologia é resultante da interação entre a lógica própria dos processos do suporte (sistemas geológico e climático) e a lógica própria dos processos sociais e culturais (antrópicos.)."
}

Essa noção está também presente na morfologia urbana que considera a forma urbana um produto das resoluções (as normas urbanísticas) aplicadas sobre o espaço ao longo do tempo.

As formas urbanas foram, então, assim consideradas, porque as complexidades de seus componentes exigem a adoção de um método de análise específico, sendo adotado o instrumental, contido na morfologia urbana ${ }^{5}$.

A identificação de um tecido urbano é feita por meio do levantamento das características gerais de seus elementos construídos, pela projeção de edificação no solo, pelo número de pavimentos, pelas características do estilo arquitetônico e pelo uso do material de revestimento. 
Há "tipos" que podem ser reconhecidos como os que melhor representam os produtos naquele determinado período de tempo'.

\section{4 - A APLICAÇÃO DOS MÉTODOS DA MORFOLOGIA URBANA NA ANÁ- LISE DAS FORMAS URBANAS EM QUESTÃO}

Dos procedimentos contidos nas três escolas de morfologia urbana foram selecionados alguns que forneceram o aporte para a identificação e a seleção dos elementos das formas urbanas de Nova Lima. A teoria sobre o aparecimento dos núcleos urbanos oriundos das rotas de circulação aplica-se à formação dos espaços urbanos em questão e esta foi utilizada na definição da estruturação dos corredores urbanos e vetores de ocupação urbana. Esses padrões, por sua vez, são conseqüentes da aplicação de certas tendências ideológicas e artísticas que influenciaram o estilo arquitetônico, o uso do material de revestimento, que definiram padrões os quais configuram um determinado tecido urbano (TAFURI ${ }^{7}, 1980$ ).

A estruturação espacial urbana local e, conseqüentemente, sua forma, são resultantes de um processo socioeconômico que, ao longo de sua história - período compreendido entre 1693 e 2005 - foi responsável pelo estabelecimento de formas particulares - quatro no total - as quais, em 2005, interagem entre si, constituindo-se na paisagem resultante de quatro períodos, a saber:

- O primeiro período que se estende de 1693 a 1890 corresponde à descoberta do ouro e à exploração das minas de aluvião, a qual ocorreu no vale do rio das Velhas, dando origem aos núcleos de Congonhas de Sabará e Morro Velho ${ }^{8}$. Os resultados típicos formais desse período podem ser encontrados na área central da cidade caracterizada por uma via de penetração longitudinal que se abre em praças e largos, delimitados por casario contínuo de um a dois pavimentos, construído no alinhamento dos lotes.

Em 1834 houve a implantação da companhia Saint John Del Rey em Nova Lima. Esse período - 1693 a 1890 - termina com a implantação da estrada de ferro no vale do rio das Velhas.

- O segundo período, o republicano, está compreendido entre 1890 e 1939, caracterizado pela internacionalização dos direitos minerários e da exploração subterrânea do ouro. A Saint John Del Rey Mining Company concentra, no período, a propriedade de inúmeras minas de ouro e grande parte do território da região do alto rio das Velhas. Bairros e vilas, construídos pela companhia para seus funcionários, seguindo padrões ingleses de companhias industriais vitorianas, representam o produto da época.

- O terceiro período vai de 1939 a 1987, quando ocorre o desenvolvimento econômico da região. Em 1973 é delimitado o primeiro perímetro da região metropolitana de Belo Horizonte, com a inclusão do município de Nova Lima em sua área de influência. A partir dessa época, inicia-se a conurbação das áreas limítrofes do município de Belo Horizonte e sua expansão sul em direção ao município de Nova Lima. Como produto característico desse período têm-se os bairros construídos para a população de baixa renda e condomínios fechados e bairros de baixa densidade, para camadas de alta e média rendas, construídos de acordo com as normas vigentes na zona rural contidas na Lei Federal n. 6.766 de 1979.

- O último período compreende o espaço de tempo situado entre 1987 e 2005.

Esse período é caracterizado pela decadência da extração aurífera, com o predomínio da exploração do minério de ferro e, na expansão metropolitana, com a ocupação das bordas dos municípios. Há a inserção da variável ambiental e esta exerce significativa influência no parcelamento do solo.

O produto típico desse período está contido ou nas bordas metropolitanas, ou junto dos eixos viários diversos. Constitui-se de condomínios e áreas de serviços e comércio agregados à mancha urbana de Belo Horizonte, caracterizando tecido típico dos bairros verticalizados 
adjacentes. Os outros produtos são encontrados ao longo dos eixos viários e constituem-se de grandes áreas destinadas aos serviços e indústria, como também condomínios fechados horizontais e bairros residenciais de classe baixa.

\section{5 - OS TECIDOS URBANOS DE INFLUÊNCIA INGLESA DA CIDADE DE NOVA LIMA}

Este trabalho apresenta os produtos resultantes das resoluções implantadas pela companhia inglesa em Nova Lima, analisadas de acordo com as seguintes variáveis:

\section{- O tempo}

O tempo está compreendido entre o segundo e terceiro períodos de desenvolvimento urbano daquela cidade e corresponde aos anos de 1834 a meados de 1950.

\section{- As resoluções das "model victorian industrial company towns" - Origens}

A companhia inglesa Saint John Del Rey Mining Company adquire os direitos de exploração minerários e fundiários da Fazenda Morro Velho, em 1834. Essa companhia se estrutura por meio de capital inglês de sócios pertencentes à classe média inglesa, denominados fabianos?.

A sede da Saint John Del Rey Mining Company estava sediada em Londres e estruturouse com capital de sócios cujas ações são comercializadas na bolsa de Londres ${ }^{10}$, de onde as decisões eram tomadas e encaminhadas ao superintendente no Brasil.

As negociações para a aquisição da Fazenda Morro Velho e as normas para sua implantação foram estabelecidas por intelectuais de classe nobre e alta inglesa. A companhia de mineração Saint John Del Rey Mining Company sofria a influência das políticas típicas de "company towns"1", da própria Inglaterra, e do norte dos Estados Unidos. Essa influência seria observada pela adoção de uma ideologia paternalista, que propunha o fornecimento de habitação para todos os trabalhadores escravos e livres empregados na mina, como também a possibilidade de compras em armazéns conveniados. Nessa época, as experiências de "companies towns" inglesas, principalmente as de Manchester, Birmingham e Liverpool, já estavam bastante disseminadas por toda a Inglaterra ${ }^{12}$.

O modelo das casas em renque era de fácil reprodução, sendo o utilizado para abrigar escravos e mesmo os trabalhadores pouco qualificados. Os modelos urbanísticos típicos das cidades inglesas industriais vitorianas são implantados em Nova Lima e, posteriormente, seriam estendidos para diversos núcleos do vale do rio das Velhas.

Sobre esse tipo de organização, Morley et al ${ }^{13}$ comentam:

"The functional layouts of Unwin, pioneered in the three most important and influential planning schemes in the early 1900s, New Earswick (1901), Letchworth Garden City (1904) and Hampstead Garden Suburb (1904), resulted in environmental standards being set which were not eclipsed for many years.

These private developments made massive contributions to Town Planning in its embryo years. Low density residential planning with semi-detached houses designed in a variety of cottage styles within a setting of open space and foliage was discovered to be a subtle remedy to urban ills. Importantly, too, these standards were employed within other schemes, which produced an international culture of superior environmental quality."

$\mathrm{Na}$ Inglaterra esse tipo de urbanização dá origem à criação de distritos administrativos locais, públicos, administrados pelos municípios; porém, na Companhia Saint John Del Rey isso acontece em caráter privativo, sob responsabilidade do departamento de manutenção daquela companhia. 


\section{- As normas urbanísticas}

O esquema urbanístico para a construção da cidade industrial baseava-se nos seguintes princípios ideológicos:

- O controle exercido pela construção de bairros isolados, anexados ao núcleo original;

- a hierarquia funcional materializada por diferentes tipos residenciais;

- a melhor forma de implantação no relevo, evitando cortes e aterros;

- a reprodução de modelos tipológicos;

- a recriação de uma paisagem urbana inglesa, com vegetação e implantação de um sistema viário sinuoso.

A partir dessa definição, a companhia inglesa organiza ${ }^{14}$ os espaços para habitações de acordo com a função hierárquica do funcionário. Os bairros residenciais de baixa densidade seriam destinados aos funcionários mais graduados. $\bigcirc$ projeto de parcelamento seria caracterizado por tipologia de parcelamento orgânico controlado por portarias. Esse tipo de implantação, seguindo um modelo orgânico, pode ser observado, também, nos bairros destinados à ocupação de funcionários menos graduados, estruturado por meio de uma via de penetração que distribui as ruas de acesso aos conjuntos morfológicos, implantados nas encostas.

As ruas são materializadas e contêm sarjetas profundas, situadas próximas ao alinhamento das casas, para a canalização da água pluvial, conduzida para grotas de alta declividade.

Nas unidades residenciais constroem-se fossas sépticas.

Além disso, havia a previsão de todos os equipamentos de apoio: escolas, hospitais, hospedagens no campo para filhos de funcionários nas férias ou fins de semana e equipamentos esportivos.

Em Nova Lima todas essas facilidades foram implantadas, a princípio ao redor da mina velha e, posteriormente, estenderam-se no sentido leste e oeste, circundando a vila original de Congonhas de Sabará.

Nos projetos que continham os croquis das edificações observa-se a recomendação:

"The country around about the mine is hilly and mountainous consequently it is not always possible to allow the garden to be in the position shown in the detach and semidetached houses, but every endeavor will be made to let the workpeople have a garden."

Lynch $^{15}$ depõe:

"[...] os britânicos construíram muitos assentamentos como estes no qual a motivação principal era o controle sobre os outros, assim com as principais emoções dos conquistadores eram o orgulho, o medo e um sentimento de exílio... A sociedade estava minuciosamente estratificada e o assentamento distinto estava distribuído em categorias funcionais, padrão salarial e lugar da residência. A altura da cota da implantação da residência e da visibilidade panorâmica era empregada para expressar o domínio social. Os ingleses viviam em complexos de baixa densidade, nos quais havia lugares para recreação, e na medida do possível, paisagens inglesas. O espaço era utilizado para expressar a distância social e controlar os contatos entre nativos e colonizadores. Toda a paisagem foi estruturada para fazer tornar visível e concretizar a estrutura social imposta. A separação era controlada e ao mesmo tempo se controlava, nostalgia dos estrangeiros e a ansiedade dos intrusos."

\section{6 - OS PRODUTOS DAS "MODEL VICTORIAN INDUSTRIAL COMPANY TOWNS"}

Os produtos foram analisados em duas categorias básicas: o parcelamento do solo e as tipologias edilícias, tanto residências quanto não-residências.

Dessa classificação pode-se identificar cerca de quatro tecidos urbanos a fazerem parte do produto da época, que contém cerca de dez tipos residenciais. 


\section{1 - O tecido urbano $2^{16}$}

O tecido urbano 2 é representado por edifícios destinados a atividades fabris e derivadas. Esse tecido é composto por galpões, terminais, escritórios, almoxarifados e áreas de beneficiamento das atividades exploratórias do ouro inseridas em Nova Lima.

Materializa-se no rigor organizacional e formal da distribuição das atividades no espaço destinado ao beneficiamento do ouro, em detrimento do caráter informal e improvisado da exploração do ouro de aluvião implantado logo após 1834.

O parcelamento é conseqüência da adaptação do relevo local, muito irregular e de alta declividade, cujo arruamento se estrutura em vias que contornam as áreas de alta declividade em níveis diferenciados, formando terraços onde as novas áreas construídas são implantadas em quadras irregulares, longitudinais, sem contornos definidos, com poucas ou quase nenhuma intercessão.

A via de penetração que reúne essas vias circundantes é sinuosa e serpenteia pelos morros ao chegar no córrego do Cardoso, desce abruptamente, para, do outro lado, continuar a subir até alcançar os bairros dos negros e o cemitério dos ingleses.
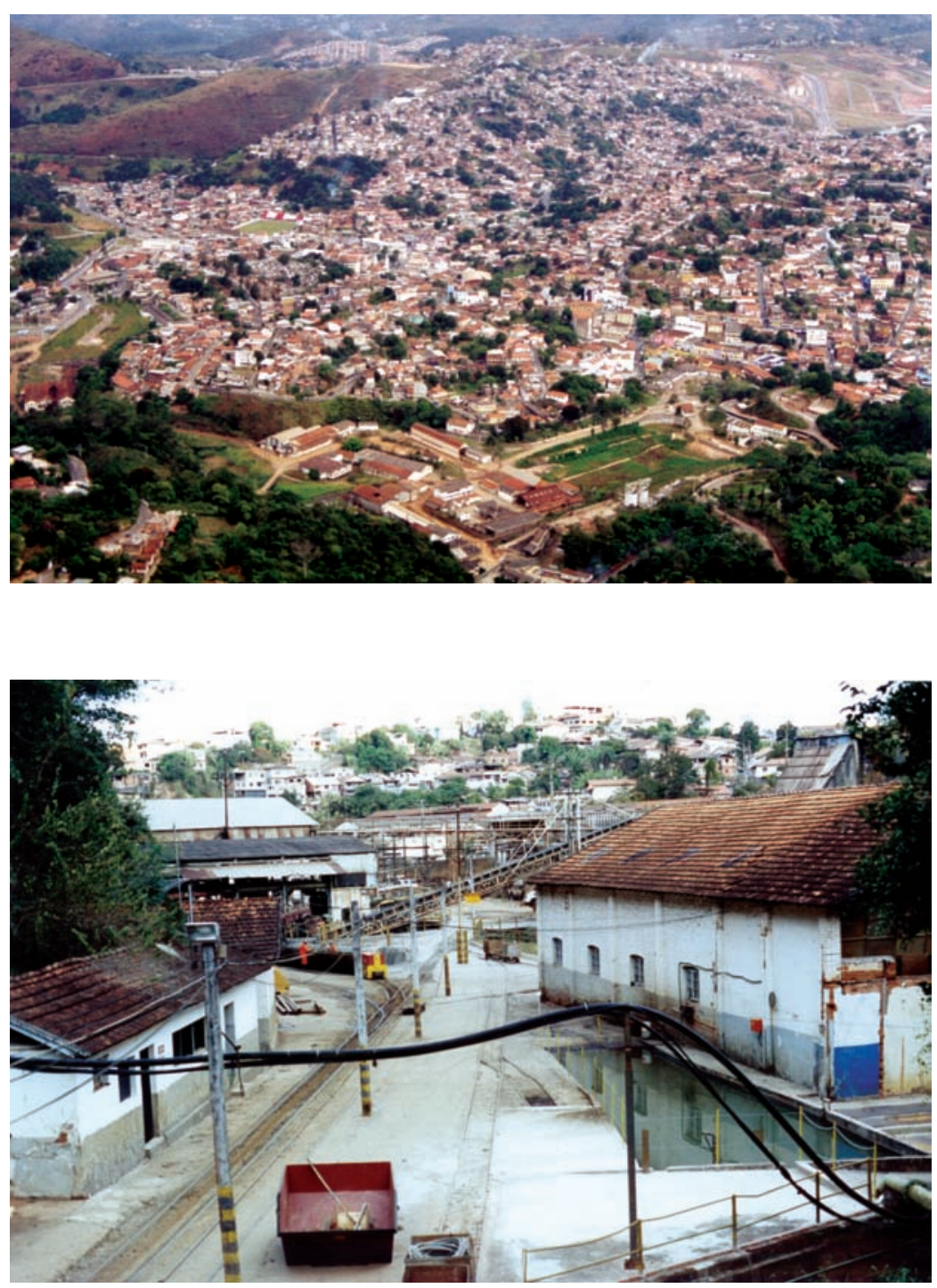

Figura 5:

Implantação do tecido urbano 2 e a cidade de Nova Lima.

As instalações industriais anexadas à área central de Nova Lima podem ser visualizadas na área pouco ocupada localizada, na parte inferior da foto

Crédito: Foto de Silvio Macedo

Figura 6:

Caracterização do tecido urbano 2.

Aspectos do tecido urbano 2 - grandes glebas contendo instalações fabris, galpões, escritórios, pátios impermeabilizados e um sistema de circulação interno ferroviário

Crédito: Autora 


\section{2 - O tecido urbano 3}

O parcelamento que caracteriza o tecido urbano 3 ocorre na forma de longos quarteirões divididos em lotes de grandes proporções, situados em encosta, onde são construídas unidades residenciais unifamiliares. Essas estão implantadas no meio do lote e recuadas das divisas. $O$ jardim se encontra na parte da frente, sob a forma de grandes gramados e, nos fundos, observam-se quintais plantados com frutíferas.

O conjunto morfológico destinado à alta chefia está implantado no platô mais proeminente, formando pequenas vias de acesso, sem saída, que levam a grandes lotes circundados por cercas vivas nas quais a unidade residencial se situa no meio do lote. Um curso d'água represado para levar água até a mina é outro elemento de estruturação que contribui para o embelezamento da área. $\bigcirc$ croqui apresenta o parcelamento no qual se observa a residência do superintendente no local mais proeminente do platô.

A residência do superintendente é construída em meio a uma área de dimensões expressivas no platô de cota mais alta, tornando-se o ponto mais visível da cidade e simboliza o poder, podendo ser visto por tudo e a todos podendo controlar.
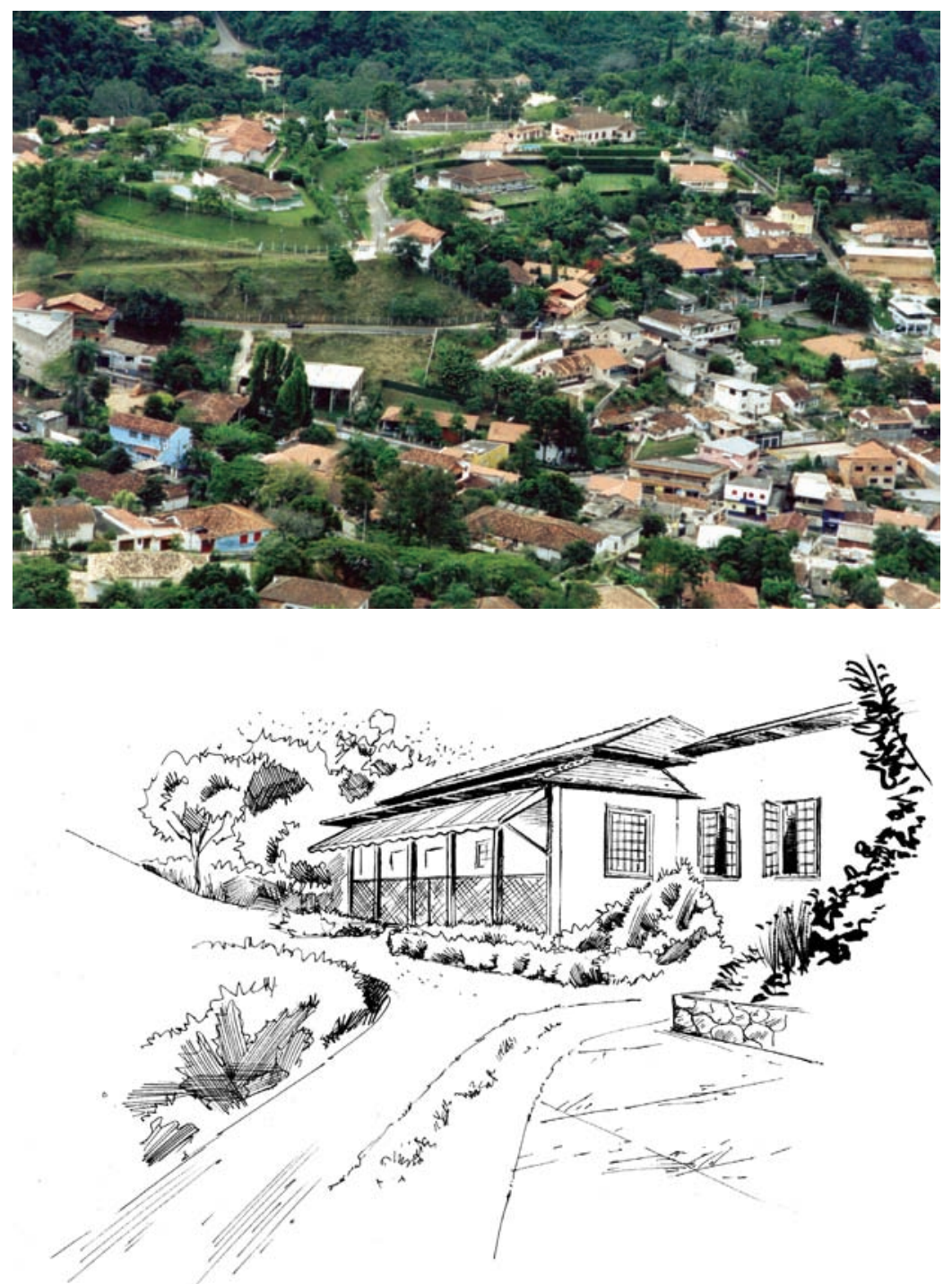

Figura 7:

A residência do superintendente.

A foto apresenta o parcelamento no qual se observa a residência do superintendente no local mais proeminente do platô. O destaque é sua implantação no platô mais alto e visível de todos os pontos da vila, isolado do conjunto, cuja implantação simboliza o poder. A visão do alto controla a todos e é vista por todos, de qualquer parte da cidade

Crédito: Foto de Silvio Macedo

Figura 8:

Tipo residencial do tecido urbano 3 , destinado à residência do superintendente da Saint John Del Rey Mining Company

Crédito: Desenho de Eduardo Pansica 
Essa grande gleba é entrecortada pelo canal (banqueta) que serpenteia pelos jardins e conduz a água até a estação hidrelétrica, visando impulsionar bombas para a refrigeração das minas.

No bairro dos funcionários há elementos tipológicos similares aos destinados às residências dos funcionários mais graduados. Esses tecidos são encontrados nos bairros de Nova Lima e destinados à moradia das chefias da Saint John Del Rey, como também para o casario da gerência. Esse tecido está implantado no local denominado bairro das Quintas.

O elemento predominante se assemelha ao da chefia - implantado próximo à mina. Esse tipo se localiza no meio do lote, rodeado por jardins e é acessado por um caminho pavimentado.

Há variação de elementos nesse tecido, com o rebaixamento formando duas residências de mesmo padrão, porém geminadas. Há também elementos semelhantes, mas com menor dimensão do que as descritas, mantendo-se o tipo de material de revestimento e a implantação do lote.

O tipo residencial é composto por conjuntos de unidades residenciais de um pavimento, às vezes geminadas e implantadas em áreas de encosta, recuadas dos limites do lote construído pela mineradora Saint John Del Rey.

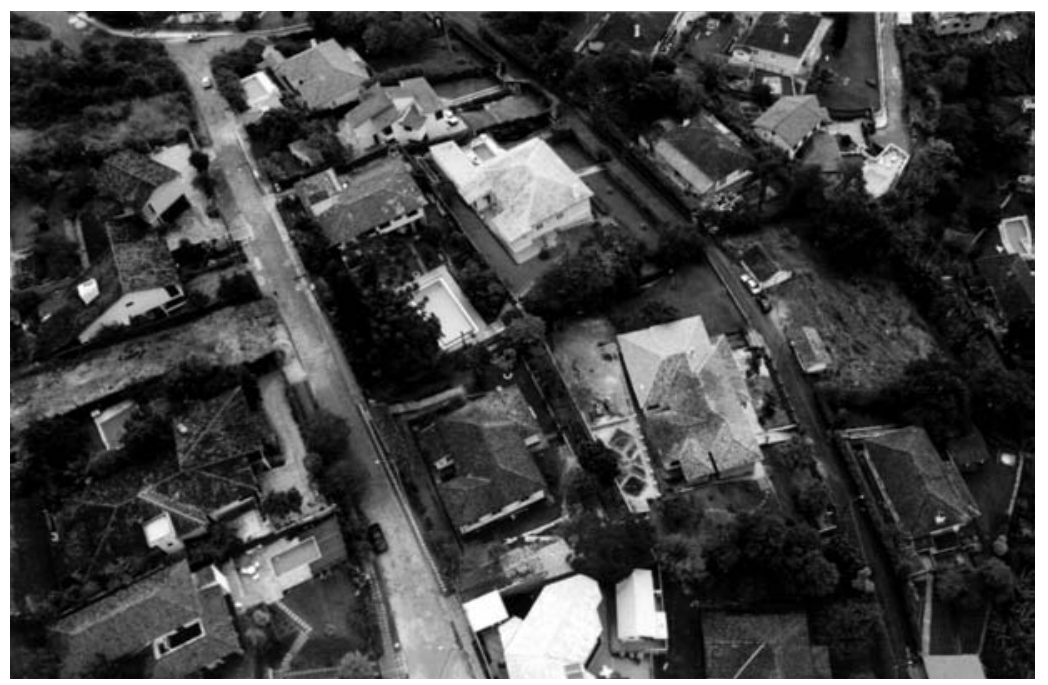

Figura 9:

Características do parcelamento do tecido urbano 3.

Aspectos do parcelamento do bairro das Quintas em Nova Lima, com quarteirões implantados em terraços e subdivididos em lotes de grandes proporções. A unidade residencial está implantada no centro do lote, com gramados no recuo frontal e quintais nos fundos, piscinas e áreas de lazer. O sistema viário não possui passeios e o limite entre vias e lote é definido por sarjetas profundas e alamedas de vegetação em cercas vivas

Crédito: Foto de Silvio Macedo

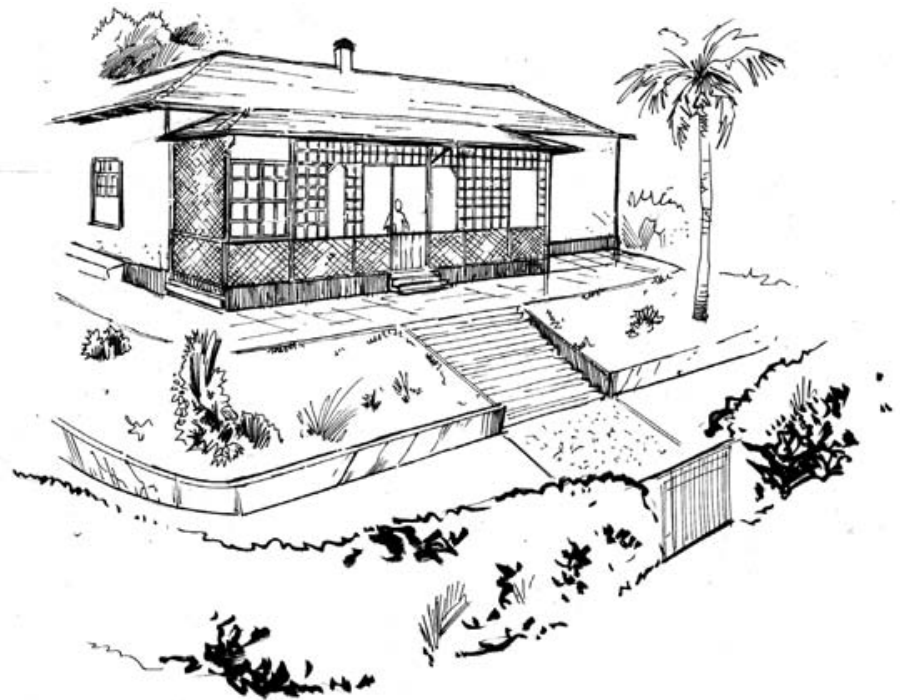

Figura 10:

Tipo residencial do tecido urbano 3 para os gerentes da Saint John Del Rey Mining Company

Crédito: Desenho de Eduardo Pansica 


\section{3 - O tecido urbano 4}

Compreende padrões de unidades-residências construídas pela companhia mineradora inglesa para abrigo dos operários, caracterizados por unidades residenciais de um pavimento, implantadas em renque, ou em "parede meia", ou em "casas solteiras"17. A implantação ocorre em terrenos planos e conformam uma malha ortogonal, geralmente nos vales próximos aos cursos d'água e nos cumes dos morros. Esses tecidos são encontrados adjacentes à área central, nos bairros Mingu, Retiro e Cristais.

A implantação do tecido urbano 4 é característica de áreas planas ou semiplanas, nas quais se procura implantar um maior número de unidades, sem custos excessivos com contenções ou terraplanagem dos terrenos. Dessa observação pode-se constatar que o princípio o qual norteava essas urbanizações sempre foi o de melhor adequação do conjunto morfológico ao relevo, para permitir a construção de maior número de unidades habitacionais.

O desmembramento dos lotes também repete o padrão diferenciado na área dos escravos. A ocupação ocorreu no alinhamento da rua, onde casas em renque são implantadas com um anexo nos fundos: tanques sanitários para lavação de roupa. A ilustração apresenta como se implantou, no período, o Conjunto Timbuctu, que constitui a primeira modalidade do tecido urbano 4.

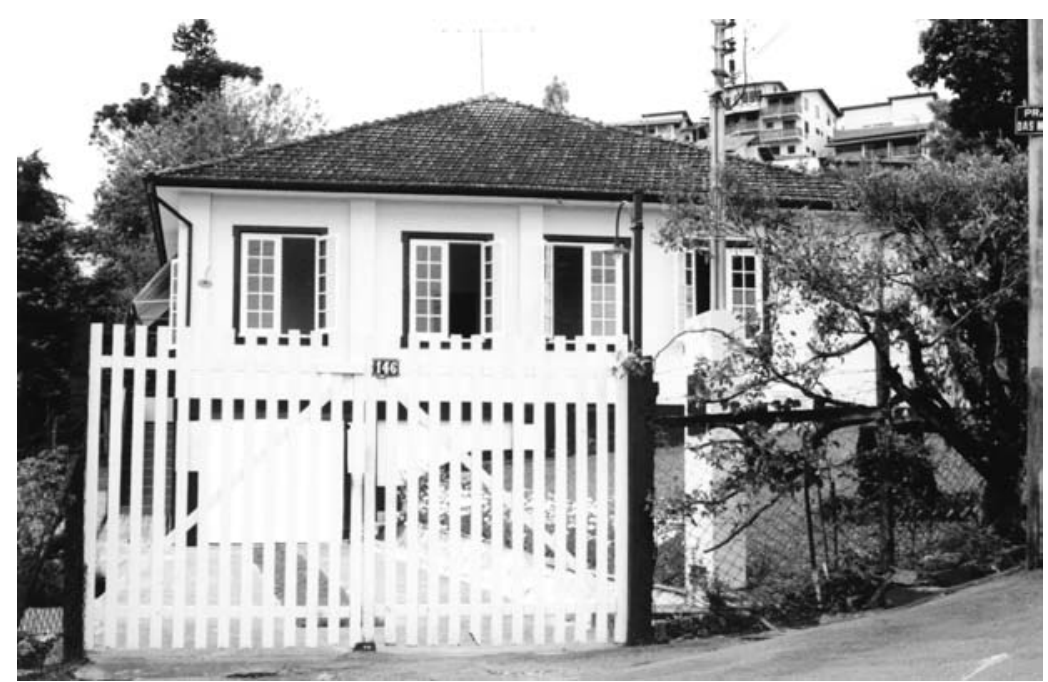

Figura 11:

Aspectos da implantação do tecido urbano 3 na paisagem

Crédito: Autora

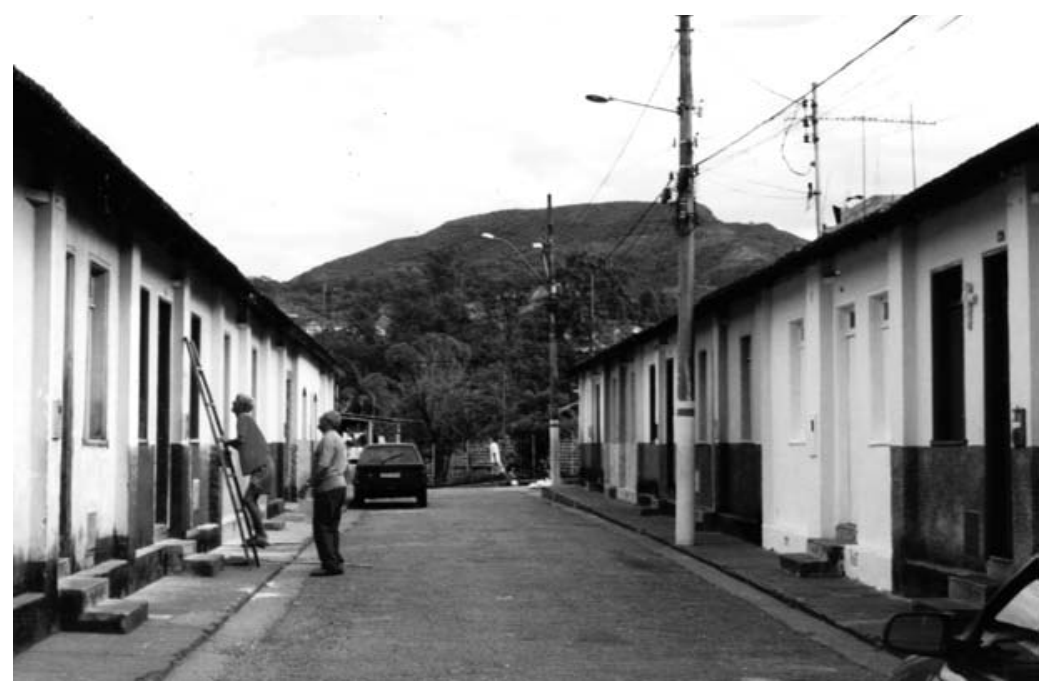

Figura 12:

Caracterização do tecido urbano 4 em Nova Lima. Aspectos dos conjuntos morfológicos residenciais construídos em renque, para os operários da Saint John Del Rey Mining Company

Crédito: Autora 


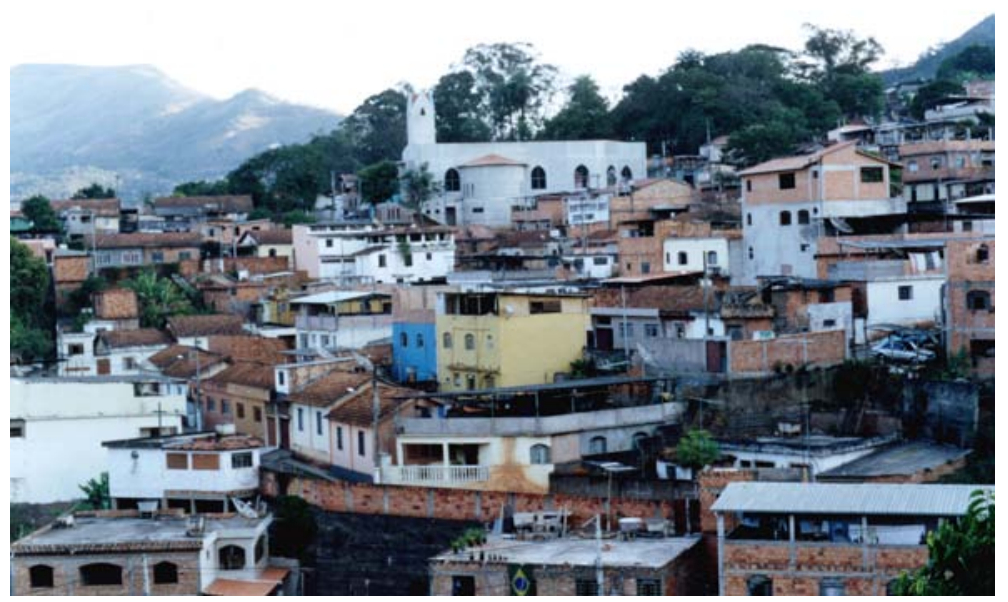

Figura 13:

Inserção do tecido urbano 4 no sítio natural em Nova Lima. Aspectos da implantação do tecido urbano 4 podem ser observados no conjunto localizado abaixo do prédio revestido na cor amarela

Crédito: Autora

\subsection{1 - Os tipos residenciais para operários do tecido ubano 4 - Variações}

Os tipos residenciais destinados aos operários são construídos em renque e localizados nas testadas dos lotes, rasos, sem quintais. $O$ pequeno espaço livre nos fundos é coletivo para implantação de instalações sanitárias e lavanderias. Há diversos tipos residenciais, todos conformando modelos consagrados em outros "industrial models for companies towns".

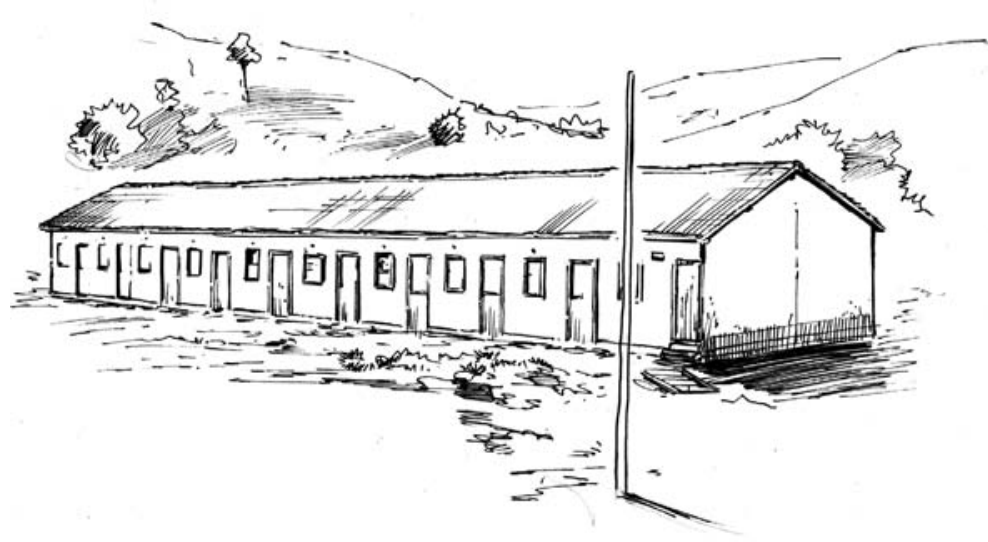

Figura 14:

Tipo residencial 1 do tecido urbano 4. Arquivos da Saint John Del Rey Mining Company.

O tipo residencial 1 se caracteriza por unidades construídas em renque $^{18}$, destinadas aos operários menos qualificados. Destinamse aos operários solteiros e são, denominados "alojamentos". Estes são compostos de 40 unidades em renque, cada uma com uma porta e uma janela na fachada, contendo um anexo com a cozinha, a lavanderia e os sanitários coletivos

Crédito: Desenho de Eduardo Pansica

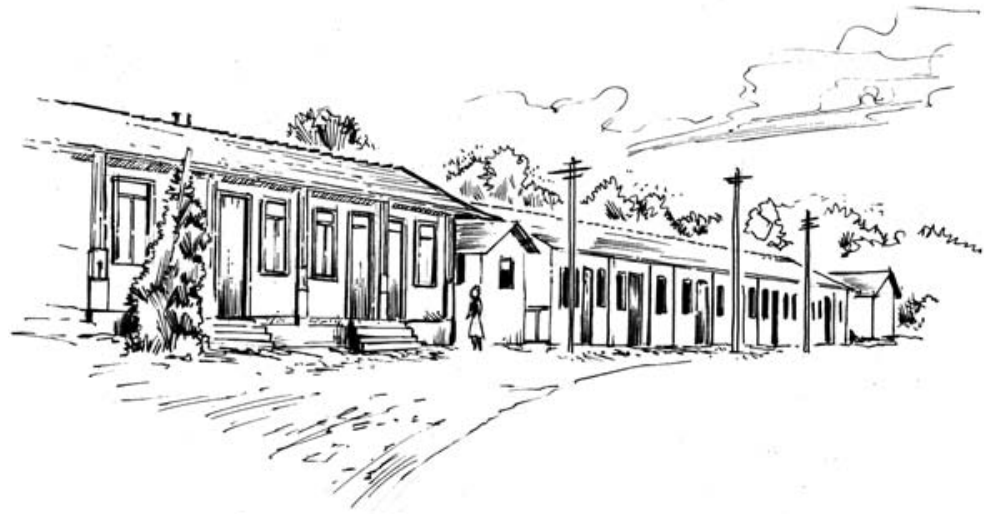

Figura 15:

Tipo residencial 2 do tecido urbano 4. Arquivos da Saint John Del Rey Mining Company.

A fachada do tipo 2 possui porta e duas janelas e as construções são denominadas "casas operárias", destinadas aos operários menos qualificados e suas famílias. São compostas de três cômodos, com os sanitários e a lavanderia em anexo, no fundo do lote

Crédito: Desenho de Eduardo Pansica 

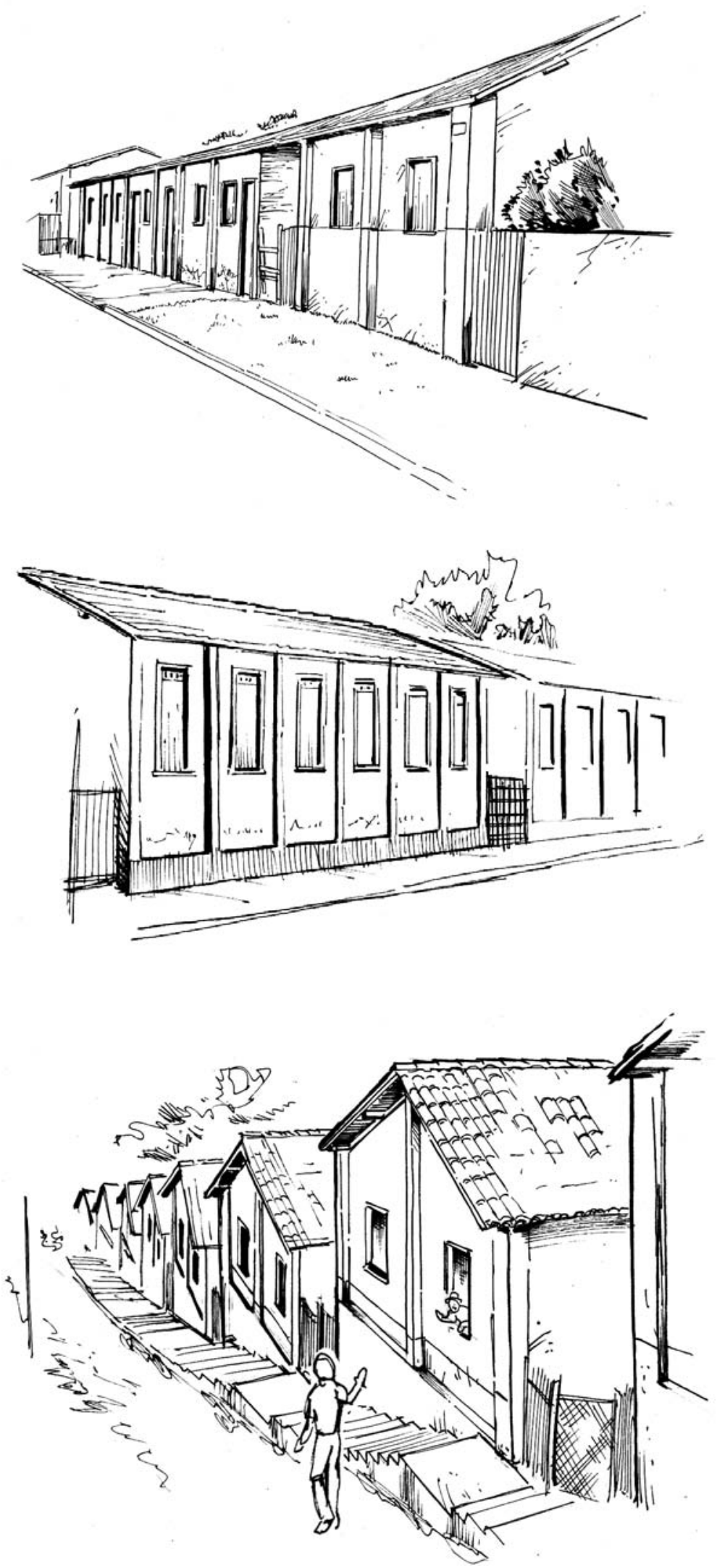

Figura 16:

Variação do tipo residencial 2 "parede meia" no tecido urbano 4.

Tipos residenciais para funcionários do tecido urbano 4. Esse tipo residencial é a casa geminada, como uma variação da residência familiar destinada aos funcionários. São construídas duas a duas, no alinhamento, com acessos laterais.

Esse tipo é denominado pela população como casa "parede meia" e cada unidade possui seu próprio sanitário

Crédito: Desenho de Eduardo Pansica

Figura 17: Variação do tipo residencial do tecido urbano 4. Há variação nos tipos residenciais que podem ser implantados três a três; e, em área de declividade excessiva, são implantados lado a lado, como se observa nos croquis

Crédito: Desenho de Eduardo Pansica

\section{Figura 18:}

Variação do tipo residencial do tecido urbano 4

Crédito: Desenho de Eduardo Pansica 


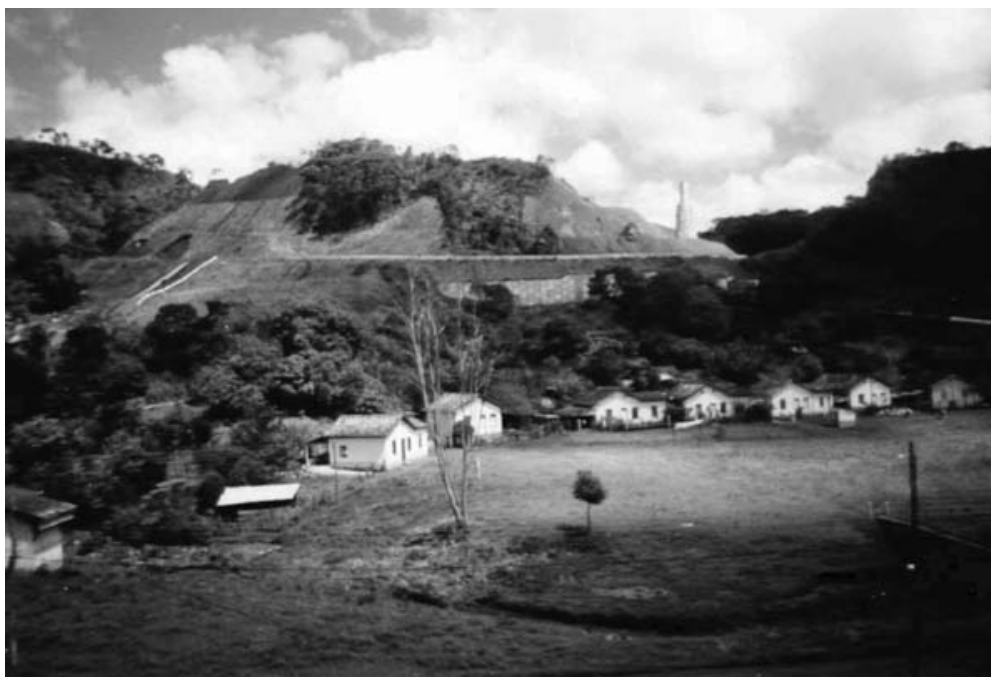

Figura 19:

Aspectos da implantação do conjunto na vila do Peixe Crédito: Autora

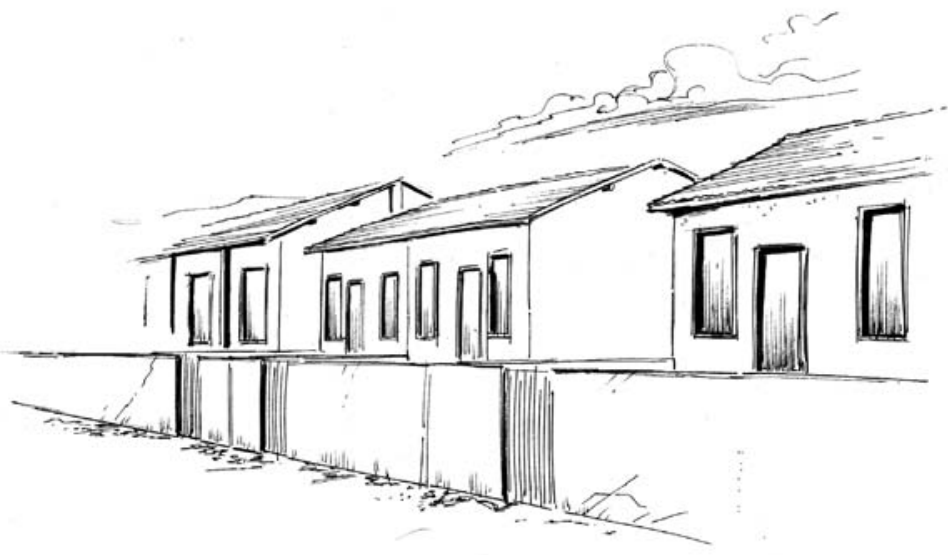

Figura 20:

Aspectos da implantação do conjunto na gleba, na vila do Galo

Crédito: Desenho de Eduardo Pansica

Uma outra variação do tecido urbano 4 pode ser identificada nas vilas que abrigam funções rurais. Essas pequenas vilas se caracterizam pela ausência de parcelamento, ou traçado de quadras e ruas organizadas de modo formal.

Os conjuntos são implantados em platô de menor declividade, compostos por uma fileira de unidades residenciais em renque, acessadas por uma estrada de terra. Podem ser encontrados na vila do Peixe, onde estão as hidroelétricas construídas para o fornecimento de energia elétrica às minas, ou na vila do Galo.

\section{4 - Tipologias não-residenciais}

A implantação de uma companhia inglesa com características capitalistas-racionalistas (1989) traz para o arraial a possibilidade de desenvolvimento pelo fornecimento de víveres, por meio de acordos com firmas particulares, tais como o efetuado com a Melo \& Cia. (mais tarde Borges, Taveira \& Cia.), varejistas na praça do Arraial de Congonhas de Sabará, em 1857.

Libby cita $^{19}$ também o abastecimento de madeira que era fornecida por lenhadores locais, cujos contratos impulsionam o comércio na vila, fato verificado pelos viajantes os quais, em décadas diferentes do período, atestaram diversos estabelecimentos.

Burton (1968) constata a existência de 20 estabelecimentos comerciais, serviços de atendimento público e indústrias caseiras, tais como um laboratório e algumas farmácias, um 
hotel denominado $\bigcirc$ Congonhense, alguns armazéns e, inclusive, uma fábrica de cerveja de produção caseira chamada Inkerman.

Essa é a primeira fase compreendida até os anos 1850, pois houve diversos acidentes envolvendo desmoronamentos e incêndios ocorridos em 1857, 1864, 1865 e, finalmente, em 1867, quando ocorreu grande incêndio, praticamente encerrando a produção da companhia e trazendo enormes prejuízos para a região de influência, o que compreendia cerca de seis ou mais municípios circunvizinhos.

\section{7 - A EVOLUÇÃO DOS TECIDOS URBANOS NO PERÍODO DE 1850 A 1950}

Para se identificar a forma urbana do período e os produtos típicos dessas resoluções foram utilizadas as descrições dos viajantes que estiveram percorrendo a região ${ }^{20}$. Desses relatos pôde-se aferir que a implantação ocorreu, a princípio, nos arredores da mina e, posteriormente, estendeu-se ao redor do núcleo original de Nova Lima.

Grandes partes das descrições sobre a forma urbana existente e os produtos típicos dessas resoluções estão presentes nos relatos dos viajantes, e desses se pôde aferir que a implantação ocorreu, inicialmente, nos arredores da mina e, posteriormente, estendeu-se ao redor do núcleo original de Nova Lima.

\section{1 - As primeiras implantações}

A área da Fazenda Morro Velho é, no início de século, um incipiente acampamento de mineração constituído de uma casa velha de fazenda pertencente ao antigo proprietário, os ranchos e senzalas pertencentes aos 34 trabalhadores livres e cerca de 70 a 122 escravos ${ }^{21}$.

Os grandes empreendimentos vão ser implementados pela companhia inglesa de mineração e os primeiros anos de atividades concentraram-se na recuperação e modernização das instalações. Esse reparo cria muitas ofertas de emprego em 1835, especialmente para carpinteiros - europeus. É grande a migração inglesa e espanhola para Congonhas de Sabará nessa época.

A principal força de trabalho, contudo, residia na mão-de-obra escrava.

Durante a aquisição da mina, 122 escravos foram transferidos para a companhia inglesa e, em 1834, 200 escravos foram comprados, enquanto o número de trabalhadores oscilava de 80 a 100.

A administração da companhia estrutura-se por departamentos em número de sete, em cuja chefia estava um responsável de cidadania européia, geralmente inglês. Todos os departamentos eram subordinados ao superintendente e havia o departamento de negros, o departamento médico, o de armazenagem, de minas, redução, manutenção e contabilidade.

A materialização dessa estrutura no espaço físico determina as primeiras ordenações de um assentamento que, no final do século, define a cidade industrial estruturada a partir da casa grande e da mina velha. $O$ córrego do Cardoso corre no fundo do vale e divide a área em duas partes: no norte ficam a mina velha e as habitações destinadas aos escravos: Boa Vista e Timbuctu, como também o Cemitério dos Ingleses.

Na vertente sul do córrego do Cardoso estão a Casa Grande, os primeiros escritórios e o conjunto morfológico destinado à alta chefia.

O segundo período após o desabamento da mina do Baú22 traz a expansão dos galpões e departamentos de apoio para a área situada ao sul do córrego do Cardoso, em uma parte baixa, e essa implantação se consolida e mantém-se até os dias atuais.

Em conseqüência do crescimento da mina, novas áreas são incorporadas e há expansão no sentido oeste, onde há ocupação incipiente do bairro do Retiro, na rua (Santo Antônio), com ocupação de casas "parede meia", em ambos os lados da rua, formando quarteirões 
longos, com lotes regulares, ocupados por construções geminadas duas a duas e recuos laterais, implantadas no alinhamento.

O padrão de ocupação se repete na rua limítrofe com a mina no sentido sul. A rua que circunda a cerca da mina tem o lado oposto a esta ocupado por casas em renque, a faixa ocupada pelo conjunto é muito estreita e não há terrenos livres para plantio ou lavanderia. A construção termina na encosta de alta declividade. Esse fato faz com que os moradores britânicos, principalmente, utilizem as cercas da mina com varal para secagem de roupas, o que a tornou conhecida como a rua do "Varal", conforme atesta Villela ${ }^{23}$.

O arraial de Congonhas possuía, em 1830, 1.400 habitantes e viria beneficiar-se e estruturar-se como base de apoio comercial e de serviços da nova companhia. Essa base de apoio vai se traduzir em novos estabelecimentos comerciais, grandes armazéns de secos e molhados e um teatro. Os primeiros assentamentos se adequam aos existentes, mas a partir de 1844 começam a ser construídas novas áreas.

\section{LEGENDA}

Vias e largos

Córregos e Ribeirões

Área ocupada

Estrada de Ferro Anglo Gold

Malha urbana de Nova Lima em 2004
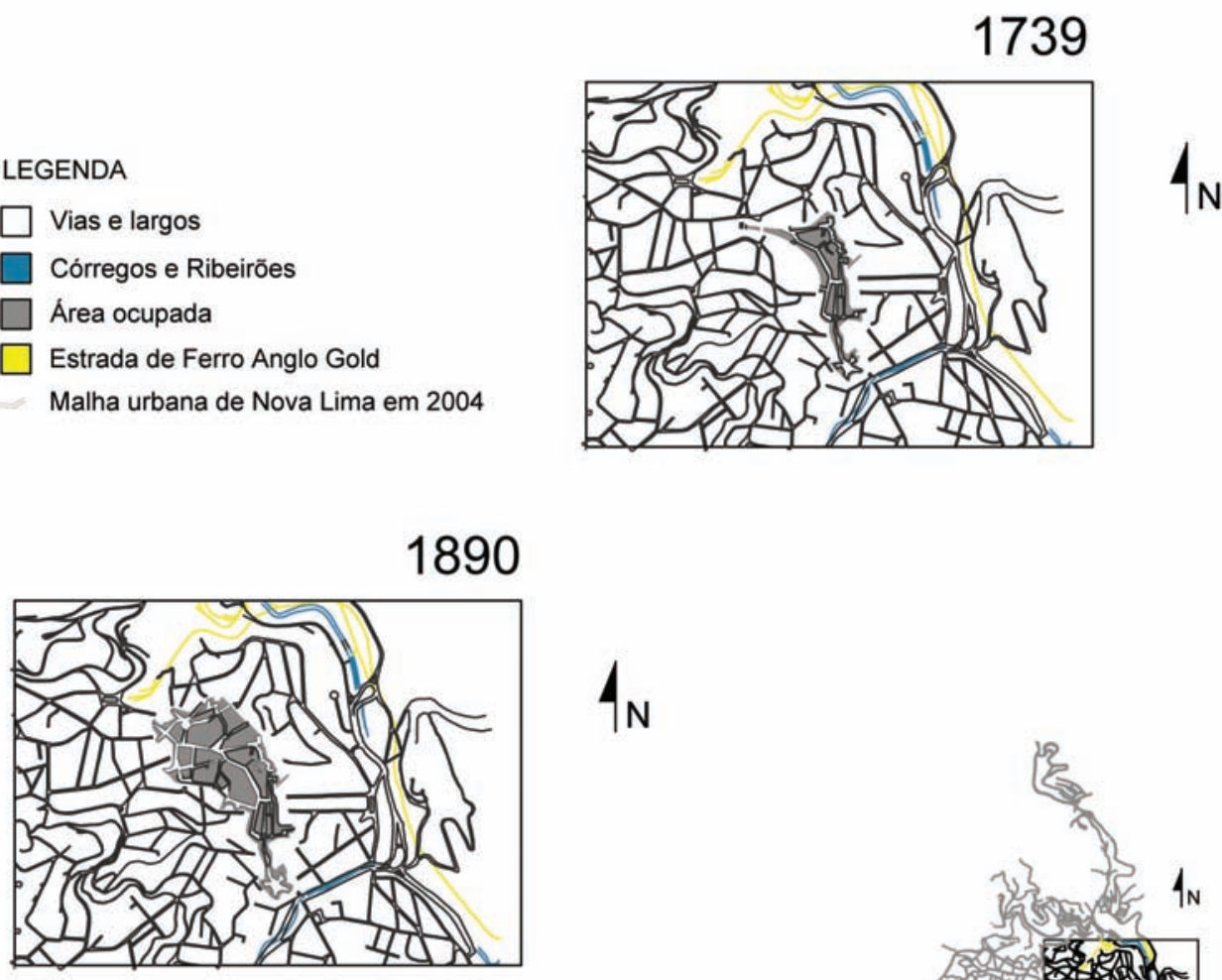

ESCALA GRÁFICA

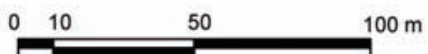

Data: Maio de 2004.

Elaboração: Stael Costa, Fabiana Furtado e Valesca Coimbra. Fonte: Mapa do Municipio de Nova Lima de 1939 - Arquivo Público Mineiro; Mapa do Municipio de Nova Lima - 2000. Prefeitura Municipal de Nova Lima, trabalho de campo 2002. 
Créditos: Stael Costa, Fabiana Furtado e Valesca Coimbra

Fonte: Arquivo Público Mineiro

\section{SÉCULO XX}

A forma da cidade, em 1939, já apresenta, de forma incipiente, sua conformação de 2004, densa, semicircular, desenvolvida ao longo de um eixo principal, limitada ao norte pelas instalações da mineração e, ao sul, pelo morro do Pires.

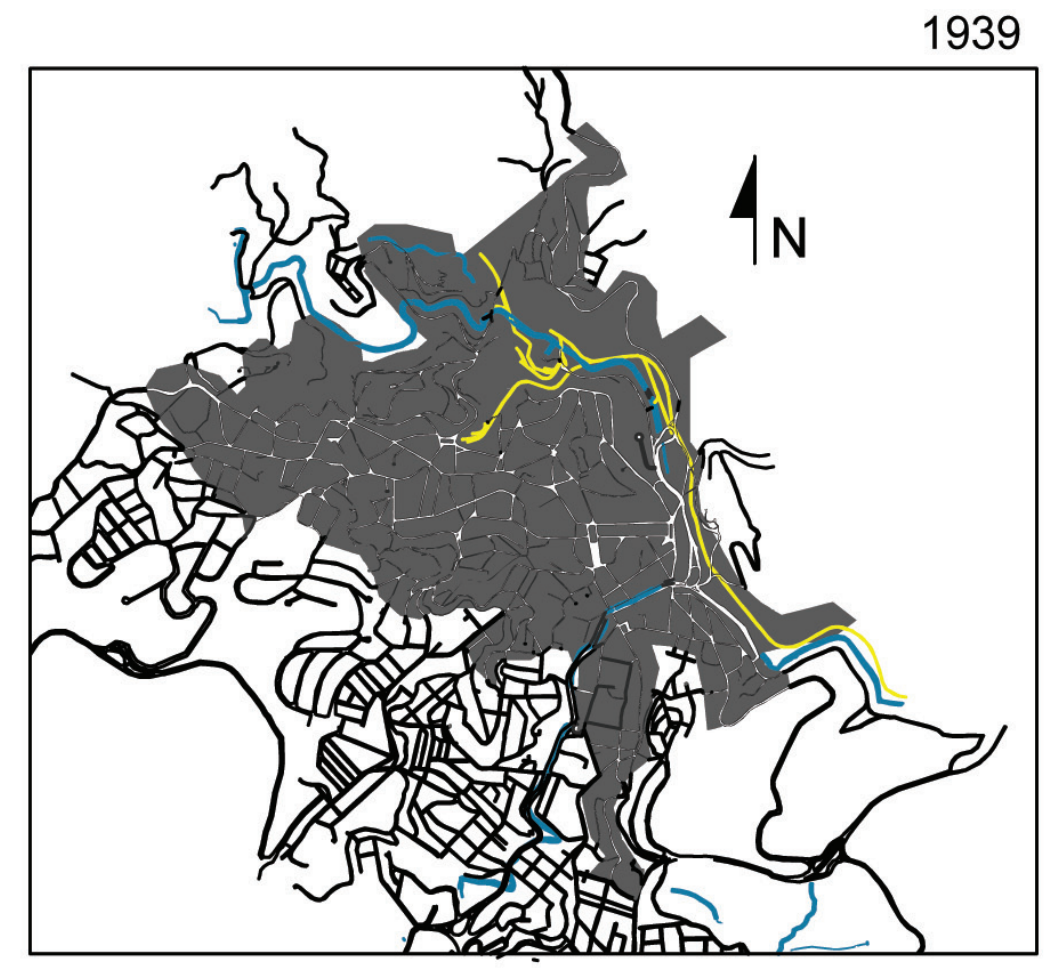

LEGENDA
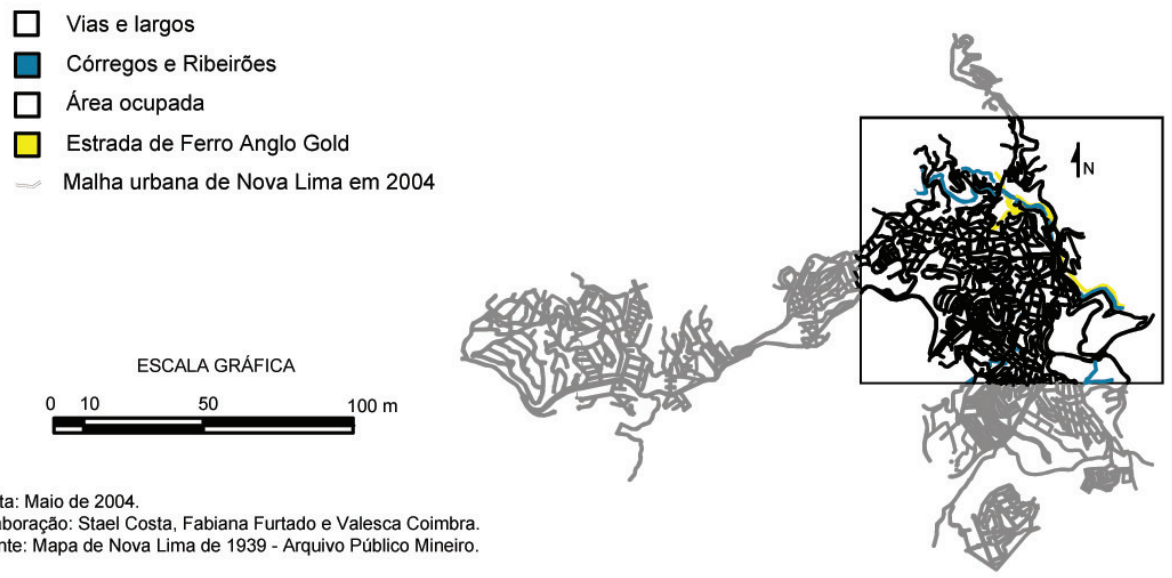

Data: Maio de 2004.

Elaboraçăo: Stael Costa, Fabiana Furtado e Valesca Coimbra.

Figura 22: Mapa da forma urbana nos meados do século XX Créditos: Stael Costa, Fabiana Furtado e Valesca Coimbra Fonte: Arquivo Público Mineiro 


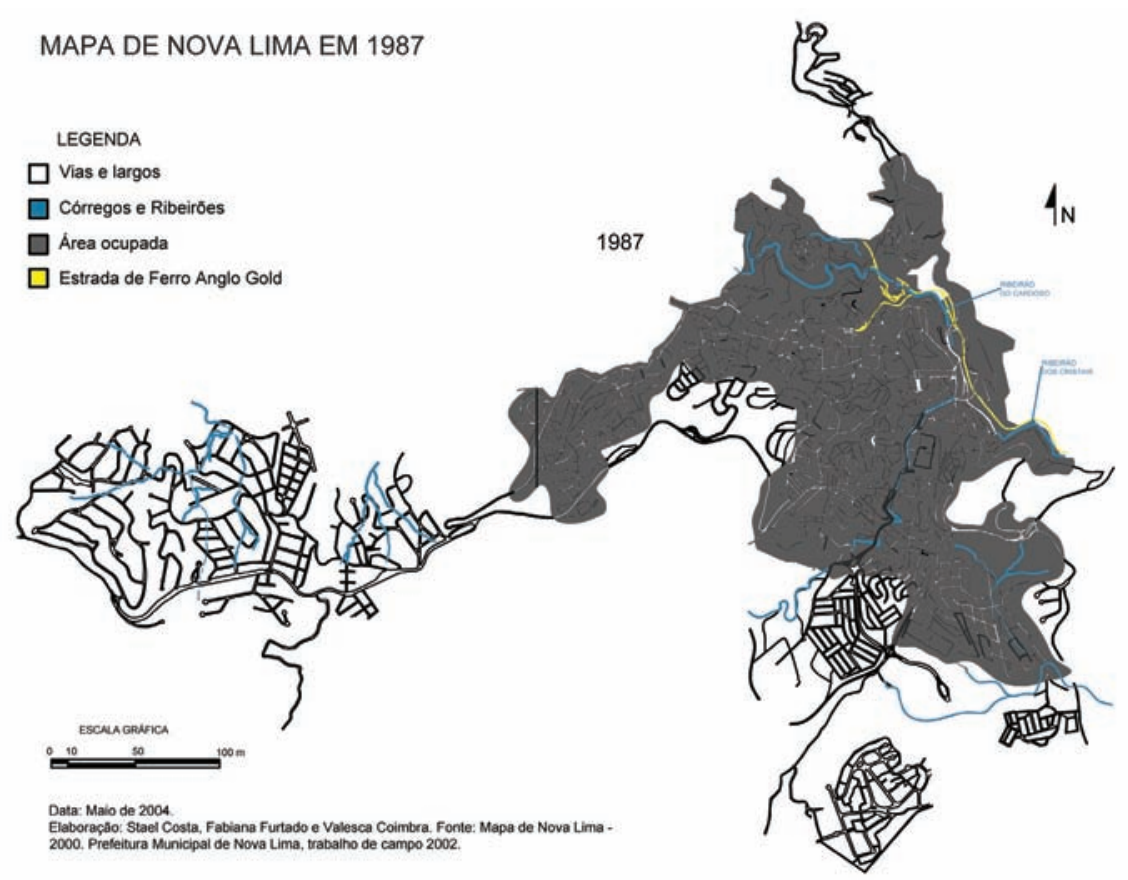

Figura 23: Mapa da forma urbana no final do século XX

Créditos: Crédito: Stael Costa, Fabiana Furtado e Valesca Coimbra

Fonte: Arquivo Público Mineiro

As instalações da companhia de mineração apresentam-se em grande expansão, induzidas pela abertura de uma nova mina, com novos equipamentos de apoio. A região é cercada por muros e configura uma barreira física às futuras expansões em direção ao norte da cidade.

Os novos conjuntos habitacionais construídos pela companhia mineradora encontram-se inseridos, ao sul, nos bairros Retiro e das Quintas. A forma urbana possui, aí, outros elementos morfológicos marcantes, tais como a banqueta no Rego Grande e o aqueduto aéreo conhecido como "Bicame". Este cruza a rua Santa Cruz e leva as águas do córrego dos Cristais e do Rego Grande, que são conduzidas pelas banquetas, para as minas.

O mapa de 1939 mostra novas áreas adjacentes ao núcleo histórico, resultantes das novas formas de parcelamento do solo as quais, no período de 1939 a 2005, integram a mancha da cidade de Nova Lima e mantêm as estruturações semicirculares, encaixadas entre as áreas da Mineração Morro Velho, ao norte, e o morro do Pires, ao sul.

Esse é o padrão encontrado presente na malha urbana de 2005, e constitui diferencial importante na história e cultura, tanto da cidade de Nova Lima quanto no estado de Minas Gerais.

\section{CONSIDERAÇÕES FINAIS}

A implantação do modelo industrial inglês na cidade de Nova Lima e seu padrão de funcionalidade podem ser identificados também nas cidades industriais mineiras implantadas no Quadrilátero Ferrífero do território de Minas Gerais.

Esses modelos urbanísticos podem ser reconhecidos nas cidades de Sabará, Raposos, Barão de Cocais, Caeté, Itabira e Rio Acima, dentre outras. Não se conhece, entretanto, estudos sistematizados que comprovem essa percepção, embora a morfologia urbana dos núcleos urbanos da região do alto do rio das Velhas comprove essa afirmativa.

Há o desconhecimento do valor cultural desses modelos urbanísticos típicos de cidades 
industriais ${ }^{24}$ de empreendimentos minerários do século XX, no estado de Minas Gerais.

As companhias mineradoras e siderurgias, grandes proprietárias desse patrimônio, não têm investido na preservação desses bens culturais.

Em Nova Lima, a Companhia Anglo Gold, que adquiriu os direitos da antiga Companhia de Mineração Morro Velho, tem promovido o parcelamento e o desmembramento das áreas, com aprovação pelo município, o que tem contribuído para sua descaracterização e perda da qualidade ambiental e cultural. Esses exemplares únicos podem ser integrados em roteiros turísticos de interpretação do patrimônio cultural, a serem divulgados como exemplos de períodos extrativos do ouro, no século XIX, na região do alto do rio das Velhas, bem como todo o circuito da Estrada Real.

A economia da cidade de Nova Lima foi sempre dependente da atividade mineral e da atividade industrial extrativista da Saint John Del Rey Mining Company, sempre atraiu população de outros locais. Observa-se, no período, um intenso processo de reforma e, portanto, de descaracterização formal das construções antigas.

Percebe-se, portanto, que, em 2005, a sociedade local ${ }^{25}$ compreende que esses elementos e artefatos fazem parte de sua herança cultural. E a indiferença antes percebida diminui - prova disso é a adesão aos programas municipais, os quais promovem ações de valorização desse patrimônio cultural. Uma delas é a que vem recuperando as "banquetas" e as áreas de preservação dos mananciais, como reservas públicas de proteção ambiental.

A preservação das áreas de mananciais e de patrimônio histórico também não era prática observada pelo poder público municipal, cujo desinteresse foi demonstrado na demolição dos exemplares arquitetônicos da memória municipal: a Casa Salles, o Casarão dos Espanhóis e, finalmente, no ano de 1990, a da casa do Marquês de Sapucaí.

No entanto, com a criação da Lei n. 12040/95, que prevê incentivos financeiros revertidos aos cofres municipais, premiando os municípios com retornos do ICMS, caso estes estabeleçam políticas efetivas de preservação ambiental e cultural, o poder publico, em 2004, tem demonstrado maior interesse pelo patrimônio. Visando aos retornos financeiros previstos, iniciou, no município, o levantamento das unidades habitacionais de autoria da companhia inglesa, para fins de preservação e interpretação.

\section{Notas}

(1) A morfologia urbana das cidades metropolitanas do ciclo do ouro. Relatório final de pesquisa. FAPEMIG, 2003.

(2) MACEDO. Quadro do paisagismo no Brasil, 1999, p. 13.

(3) Essa premissa utiliza como conceituação da visão contemporânea da paisagem, preconizada por Delpoux, que, em 1972, definia a paisagem como uma entidade espacial a qual corresponderia à soma de um tipo geomorfológico e de uma cobertura, e por Odum que, em 1976, considera-a como resultado de um processo de interação entre sua cobertura e seu suporte. "Esta visão é radicalmente oposta à visão tradicional da paisagem como região" (BLEY, Morretes: Um estudo de paisagem valorizada, 1996, p. 123) ou da visão com paisagem como um panorama. Milton Santos, em 1982, contribui para ampliar o conceito da paisagem afirmando que, 'tudo são paisagens' e todas as modalidades de paisagem estão presentes nesse sistema de relações. São paisagens, portanto, a área livre, as florestas, os rios, os espaços urbanos e periféricos, e as áreas urbanas. Desta forma o conceito se amplia para áreas urbanas serem consideradas paisagens, compreendo bairros, ruas e tecidos urbanos."

(4) MAGNOLI. Espaços livres e urbanização: Uma introdução a aspectos da paisagem metropolitana, 1982, p. 47.

(5) Sobre métodos de morfologia urbana vide PEREIRA COSTA, Stael A. (2001) in Topos, v. I, 1999, p. 81.

(6) LEVY. Urban morphology and the problem of urban fabric: Some questions for research, 1999, p. 79.

(7) TAFURI. Architecture and utopia, 1980, p. 45.

(8) VILLELA, Braulio Carsalade. Nova Lima - Formação histórica. Belo Horizonte: Gráfica e Editora Cultural, 1998. 
(9) GUNN. O paradigma da cidade jardim na Vila Fabiana da reforma urbana, 1999, p. 9.

(10) Trabalho escravo - O caso da Morro Velho, p. 58: "A compra da mina pelo capitão Lyon fazia parte de uma virtual febre "que afligiu o mercado londrino durante as décadas de 1820 a 1830 . Num curto período de quinze anos, dezenas de companhias por ações gozando de todos os benefícios de acesso ao capital social e as possibilidades de investimentos bancários, formaram-se com o objetivo de explorar as riquezas minerais da América Latina. Esta febre não passou uma investment bubble, pois esmagadora maioria das empresas faliu dentro de poucos anos." Este, contudo, não foi o caso da Saint John Del Rey Mining Company, que explorou o ouro na região do alto do rio das Velhas por mais de um século.

(1 1) MINAMI. Vila Martin Smith, no alto da serra, em São Paulo, um modelo típico de "model company town", 1994, p. 45.

(12) BENÉVOLO. As origens da urbanística moderna, 1994, p. 42.

(13) MORLEY CRAVER, A. M. - Sustainable urban development: The example of victorian cities in Britain, 1999, p. 9.

(14) Arquivos da Saint John Mining Company. Mapoteca do Centro de Memória da Cia. Anglo Gold., 1918.

(15) La buena forma de la ciudad, 1985, p. 25.

(16) Os tecidos urbanos de influência inglesa estão inseridos na antiga cidade colonial e são anexados ao Tecido Urbano 1, que se refere aos tecidos coloniais. Daí sua classificação como tecido urbano 2.

(17) Adotou-se para a classificação dos tipos o critério utilizado pela população local.

(18) MORLEY, I.; CRAVEN, A. M. Sustainable urban development: The example of victorian cities in Britain, 1999, p. 13.

(19) Trabalho escravo no Brasil; o caso de Morro Velho, p. 67.

(20) Cerca de 34 viajantes estiveram percorrendo essa região no período. Ver LEITE, 1996.

(21) Morro Velho, história, fatos e feitos, p. 74.

(22) Op. cit.

(23) Ver VILLELLA.

(24) PEREIRA COSTA. Brazilian mining cities: A mosaic of urban forms, 2001, p. 153.

(25) Outro fato que demonstra a nova postura da população com relação ao seu patrimônio cultural pode ser observado pela promoção de um abaixo-assinado, direcionado aos poderes constituídos, para que o bairro das Quintas fosse preservado, diante da ameaça de mudança de seu zoneamento, que admitiria uma maior capacidade construtiva. Informações obtidas em entrevista com a doutora Luciana Custódio dos Santos.

\section{Bibliografia}

BENÉVOLO, Leonardo. As origens da urbanística moderna. Lisboa: Editorial Presença, 1994.

BLEY, Lineu. Morretes. Um estudo da paisagem valorizada. Percepção ambiental - A experiência brasileira. São Paulo: Studio Nobel/Universidade Federal São Carlos, 1996.

DELPOUX, Marcel. Ecossistema e paisagem in série; métodos em questão. São Paulo: Universidade de São Paulo, 1997.

GUNN, Philip. O paradigma de cidade-jardim na Vila Fabiana de reforma urbana. Espaço e debates: Revista de estudos regionais e urbanos, São Paulo, ano XVII, n. 40, p. 11-27, 1997.

LIBBY, Douglas Cole. Trabalho escravo e capital estrangeiro no Brasil; o caso Morro Velho. Belo Horizonte: Itatiaia, 1984.

LYNCH, Kevin. La buena forma de la ciudad; a theory of good city form. Tradução de Eduard Mira. Barcelona: Gustavo Gilli, 1985

MACEDO, Silvio Soares. Quadro do paisagismo no Brasil. São Paulo: Quapá - FAUUSP, 1999.

MAGNOLI, Miranda Martinelli. Espaços livres e urbanização: Uma introdução a aspectos da paisagem metropolitana. 1982. Tese (Livre-docência) - Faculdade de Arquitetura e Urbanismo, Universidade de São Paulo, 1982.

MINAMI, Issao. Vila Martin Smith, no alto da serra, em São Paulo, um modelo típico de "model company town". 1994. Tese (Doutorado em Estruturas Ambientais Urbanas) - Faculdade de Arquitetura e Urbanismo, Universidade de São Paulo, São Paulo, 1994

MINERAÇÃO MORRO VELHO LTDA. Morro Velho, história, fatos e feitos. Nova Lima: Mineração Morro Velho, 1995. 
MineraÇÃo mORRO VelHO ltDA. Arquivos da Saint John Mining Company. Mapoteca do Centro de Memória da Cia. Anglo Gold., 1918 - Nova Lima: Mineração Anglo Gold Ashanti, 2000.

MORLEY, I.; CRAVEN, A. M. Sustainable urban development: the example of victorian cities in Britain. SRILANK CONFERENCE ON CITIES AND SUSTAINABILITY MILLENNIUM, 1999, Sirilanka. Srilank Proceedings... Sirilanka, 1999.

LEVY, Albert. Some questions for research. Urban Morphology Journal of International Seminar on urban form. Dorchester: Dorset Press, v. 3, n. 2, 1999.

ODUM, Howard T. Energy quality and the carrying capacity of the earth. Tropical Ecology, Cambridge, n. 16, p. 27, 1976.

TAFFURRI, M. Architecture and utopia: Design and capitalist development. 1. ed. Cambridge: The Mit Press, 1980.

PEREIRA COSTA, Staël de Alvarenga. Transformações e permanências no tempo da Savassi, Belo Horizonte. Topos, Belo Horizonte, v. 1, n. 1, p. 80-92, 1999.

A morfologia urbana das cidades metropolitanas do ciclo do ouro. Relatório final de pesquisa. Belo Horizonte: FAPEMIG, 2003

Brazilian mining cities: A mosaic of urban forms. In: INTERNATIONAL SEMINAR ON URBAN FORM, 2001, Cincinnati. Proceedings... Cincinnati, 2001.

The role of the landscape on shaping urban forms of colonial mining towns. In: The planned city? INTERNATIONAL SEMINAR ON URBAN FORM, 2003, Trani. Proceedings... Bari: Uniongrafica Corcelli Editrice, v. 1, 2003

Transformações, conflitos, perdas e permanências na paisagem sul-metropolitana de Belo Horizonte. 2004. Tese (Doutorado) - Faculdade de Arquitetura e Urbanismo, Universidade de São Paulo, 2004.

SANTOS, Milton. Pensando o espaço do homem. São Paulo: Hucitec, 1982.

VILLELA, Bráulio Carsalade. Nova Lima - Formação histórica. Belo Horizonte: Gráfica e Editora Cultural, 1998. 